\title{
Application of Modified Mesenchymal Stem Cells Transplantation in the Treatment of Liver Injury
}

\author{
Liyuan LIU ${ }^{1}$, Fuyuan YANG ${ }^{1}$ \\ ${ }^{1}$ School of Basic Medicine, Yangtze University Health Science Center, Jingzhou, China
}

Received November 26, 2020

Accepted March 15, 2021

Epub Ahead of Print May 12, 2021

\section{Summary}

Acute and chronic hepatitis, cirrhosis, and other liver diseases pose a serious threat to human health; however, liver transplantation is the only reliable treatment for the terminal stage of liver diseases. Previous researchers have shown that mesenchymal stem cells (MSCs) are characterized by differentiation and paracrine effects, as well as anti-oxidative stress and immune regulation functions. When MSCs are transplanted into animals, they migrate to the injured liver tissue along with the circulation, to protect the liver and alleviate the injury through the paracrine, immune regulation and other characteristics, making mesenchymal stem cell transplantation a promising alternative therapy for liver diseases. Although the efficacy of MSCs transplantation has been confirmed in various animal models of liver injury, many researchers have also proposed various pretreatment methods to improve the efficacy of mesenchymal stem cell transplantation, but there is still lack a set of scientific methods system aimed at improving the efficacy of transplantation therapy in scientific research and clinical practice. In this review, we summarize the possible mechanisms of MSCs therapy and compare the existing methods of MSCs modification corresponding to the treatment mechanism, hoping to provide as a reference to help future researchers explore a safe and simple transplantation strategy.

\section{Key words}

Mesenchymal Stem Cells • Liver Diseases • Gene Expression Regulation • Regeneration • Immunologic Factors

\section{Corresponding author}

F. Yang, Room East 301, No. 14 Teaching Building, Yangteze University, No. 1, Xueyuan Road, Jingzhou, Hubei Province,
434023, China. E-mail: ivansblue@sina.com

\section{Introduction}

The liver is the primary organ involved in metabolism, and as such, is the main target of toxic substances. Long-term repeated or short-term exposure to large doses of toxic substances can cause a variety of liver diseases, such as alcoholic hepatitis, drug-induced hepatitis, viral hepatitis, liver fibrosis, liver cirrhosis, that seriously affect the quality of life (Hu et al. 2020, Huang et al. 2016, Lu et al. 2020, Wan et al. 2020). Around the world, liver transplantation is still the most often used and effective treatment for acute liver failure and advanced liver diseases (Xu et al. 2017). However, due to shortage of donors, the high cost, and the allografts rejection affecting the prognosis and quality of life of patients, this therapy is not widely available (Puglisi et al. 2011). MSCs are derived from various tissues such as bone marrow, umbilical cord, placenta, amniotic fluid, gums, and fat (Lou et al. 2017), have the characteristics of self-renewal, proliferation and differentiation, and immune regulation. These cells have the potential to undergo multidirectional differentiation into osteocytes, chondrocytes, adipocytes, neuron-like cells and hepatocyte-like cells (Boyd et al. 2019, Kladnická et al. 2019, Miao et al. 2016). Therefore, stem cells transplantation can be used to repair damaged tissues through their ability of homing to the liver, where they undergo proliferation and differentiation, and secrete cytokines to regulate the liver humoral environment to reduce injury (Eom et al. 2015, Hu et al. 2019, Yan et al. 
2009). Vascularization promotion also serve as an explanation of MSCs function (Pytlík et al. 2017). In addition, MSCs can regulate immune responses and induce tolerance to antigens, with the ability to regulate the activities of various immune cells, such as inhibiting the proliferation and function of $\mathrm{T}$ cells, B cells and NK cells (Gazdic et al. 2017). The ability of MSCs to proliferate, differentiate and their effect on immune regulation highlights the potential of these cells for the treatment acute and chronic liver injury (Eom et al. 2015, Fathi et al. 2019, Gazdic et al. 2017).

It has been found that MSCs transplantation is a safe and highly feasible option for the treatment of liver diseases; however, further studies are required to clarify many aspects of the application of MSCs transplantation, such as the underlying mechanism of MSCs treatments and strategies to improve the therapeutic effect. In fact, different attempts have been made to improve the efficacy of MSCs in the treatment of liver diseases (Table 1). Understanding various methods to improve the efficacy of MSCs transplantation in liver diseases is of great significance for the further improvement and clinical application of MSCs therapy.

Table 1. MSCs modification strategies and effects.

\begin{tabular}{|c|c|c|c|c|c|c|c|c|}
\hline $\begin{array}{l}\text { MSCs } \\
\text { source }\end{array}$ & Modification & Dose & Route & Animal & Cause & Effect & Mechanisms & References \\
\hline Adipose & $\begin{array}{l}\text { HGF and FGF4 } \\
\text { pretreated MSCs }\end{array}$ & $1 \times 10^{6}$ & Intrahepatic & Mice & $\mathrm{CCl}_{4}$ & $\begin{array}{c}\text { Restored glycogen storage } \uparrow \text {, } \\
\text { collagen } \downarrow \text {, ALP } \downarrow \text {, bilirubin } \downarrow \text {, } \\
\text { LDH } \downarrow \text {, anti-apoptotic, greater } \\
\text { homing of MSCs in liver }\end{array}$ & $\begin{array}{l}\text { Transdifferentiation of } \\
\text { MSCs into } \\
\text { hepatocytes-like cells, } \\
\text { improvement of liver } \\
\text { function and in } \\
\text { reduction of fibrosis }\end{array}$ & $\begin{array}{c}\text { Shams et al. } \\
2015\end{array}$ \\
\hline $\begin{array}{l}\text { Bone } \\
\text { marrow }\end{array}$ & $\begin{array}{l}\text { Pretreated with } \\
\text { HGF or } \\
\text { SU11274 (c-Met } \\
\text { inhibitor) }\end{array}$ & $3 \times 10^{6}$ & Tail vein & Rats & $\mathrm{I} / \mathrm{R}$ injury & $\begin{array}{c}\text { ALT } \downarrow, \text { AST } \downarrow, \text { C-met } \downarrow \text {, hepatic } \\
\text { histopathological change }\end{array}$ & $\begin{array}{l}\text { Upregulated c-Met } \\
\text { and phosphorylated } \\
\text { Met expression }\end{array}$ & $\begin{array}{l}\text { Liu et al. } \\
2014\end{array}$ \\
\hline $\begin{array}{l}\text { Umbilical } \\
\text { cord }\end{array}$ & $\begin{array}{l}\text { Rapamycin or } \\
\text { 3-methyladenine }\end{array}$ & $1 \times 10^{6}$ & Intravenous & Mice & I/R injury & $\begin{array}{l}\text { ALT } \downarrow, \text { AST } \downarrow \text {, Caspase- } 3 \downarrow \text {, } \\
\text { hepatic histopathological change }\end{array}$ & $\begin{array}{l}\text { Preconditioning with } \\
\text { rapamycin enhances } \\
\text { the ability of UC- } \\
\text { MSCs to home } \\
\text { towards ischemic liver } \\
\text { tissue by increasing } \\
\text { the expression of } \\
\text { CXCR4 }\end{array}$ & $\begin{array}{c}\text { Zheng et al. } \\
2018\end{array}$ \\
\hline $\begin{array}{l}\text { Bone } \\
\text { marrow }\end{array}$ & $\begin{array}{l}\text { Cultured under } \\
\text { hypoxic }\end{array}$ & $\begin{array}{l}1 \times 10^{6} \\
2 \times 10^{5} \\
4 \times 10^{4}\end{array}$ & Tail vein & Mice & $\mathrm{CCl}_{4}$ & $\begin{array}{l}\text { RNA expression levels of Ptges } \\
\text { and microRNA210 } \uparrow \text {, ALT } \downarrow \text {, } \\
\text { oxidative stress } \downarrow \text {, and fibrosis } \downarrow \text {, } \\
\text { hepatocyte apoptosis } \downarrow \text {, changed } \\
\text { macrophage polarity to an anti- } \\
\text { inflammatory }\end{array}$ & $\begin{array}{l}\text { Upregulated } \mathrm{PGE}_{2} \text { and } \\
\text { miR2 } 10 \text { expression }\end{array}$ & $\begin{array}{l}\text { Kojima et } \\
\text { al. } 2019\end{array}$ \\
\hline $\begin{array}{l}\text { Human } \\
\text { umbilical } \\
\text { cord blood }\end{array}$ & $\begin{array}{l}\text { Transfected with } \\
\text { the pMEX-HGF } \\
\text { plasmid }\end{array}$ & $2 \times 10^{6}$ & Tail vein & Rats & $\mathrm{CCl}_{4}$ & $\begin{array}{c}\mathrm{ALT} \downarrow, \mathrm{AST} \downarrow, \mathrm{ALP} \downarrow \text {, collagen } \\
\text { fibres } \downarrow\end{array}$ & $\begin{array}{l}\text { HGF overexpressing } \\
\text { in human UCB-MSCs }\end{array}$ & $\begin{array}{l}\text { Kim et al. } \\
\quad 2011\end{array}$ \\
\hline $\begin{array}{l}\text { Bone } \\
\text { marrow }\end{array}$ & $\begin{array}{l}\text { Expression of } \\
\text { antisense of } \\
\text { microRNA-26a- } \\
\text { 5p to increase } \\
\text { HGF production }\end{array}$ & $1 \times 10^{6}$ & $\mathrm{~N} / \mathrm{A}$ & Mice & $\mathrm{CCl}_{4}$ & $\begin{array}{c}\text { HGF } \uparrow \text {, fibrotic area } \downarrow \text {, portal } \\
\text { pressure } \downarrow \text {, sodium excretion } \uparrow\end{array}$ & $\begin{array}{c}\text { Suppression of } \\
\text { microRNA-26a-5p to } \\
\text { increase HGF } \\
\text { production }\end{array}$ & $\begin{array}{l}\text { Seo et al. } \\
2014\end{array}$ \\
\hline $\begin{array}{l}\text { Bone } \\
\text { marrow }\end{array}$ & Nigella sativa oil & $1 \times 10^{6}$ & Tail vein & Rats & $\begin{array}{l}\text { Exposure } \\
\text { to } \gamma \\
\text { radiation }\end{array}$ & $\begin{array}{c}\mathrm{ALT} \downarrow, \mathrm{AST} \downarrow, \mathrm{MDA} \downarrow, \mathrm{SOD} \uparrow, \\
\mathrm{IL}-6 \downarrow, \mathrm{TNF}-\alpha \downarrow, \\
\mathrm{IL}-10 \uparrow, \mathrm{TGF}-\beta \uparrow\end{array}$ & $\begin{array}{l}\text { Improvement of liver } \\
\text { function and reduction } \\
\text { of oxidative stress, } \\
\text { inflammatory and } \\
\text { fibrogenic }\end{array}$ & $\begin{array}{l}\text { Farouk et al. } \\
2018\end{array}$ \\
\hline
\end{tabular}




\begin{tabular}{|c|c|c|c|c|c|c|c|c|}
\hline $\begin{array}{l}\text { Bone } \\
\text { marrow }\end{array}$ & $\begin{array}{c}\text { Intervening } \\
\text { UCHL1 by } \\
\text { shRNA } \\
\text { knockdown or its } \\
\text { inhibitor } \\
\text { LDN57444 or } \\
\text { overexpression }\end{array}$ & $1 \times 10^{6}$ & Tail vein & Mice & Con-A & $\begin{array}{c}\text { iNOS } \uparrow \text {, percentages of necrosis } \\
\text { area } \downarrow \text {, mononuclear cells } \downarrow \text {, } \\
\text { CD4+ and CD8+ T cells } \downarrow\end{array}$ & $\begin{array}{l}\text { UCHL1 inhibition } \\
\text { promotes the } \\
\text { activation of NF-אB } \\
\text { and STAT1 signaling } \\
\text { and suppressed } \\
\text { apoptosis of MSCs via } \\
\text { upregulation of Bcl-2 }\end{array}$ & $\begin{array}{c}\text { Radwan and } \\
\text { Mohamed } \\
2018\end{array}$ \\
\hline $\begin{array}{l}\text { Bone } \\
\text { marrow }\end{array}$ & $\begin{array}{c}\text { Recombinant } \\
\text { HNF-4 } \alpha \\
\text { overexpression } \\
\text { adenovirus } \\
\text { transfection }\end{array}$ & $1 \times 10^{6}$ & Tail vein & Mice & $\mathrm{CCl}_{4}$ & $\begin{array}{c}\text { ALT } \downarrow, \text { AST } \downarrow, \text { TNF- } \alpha \downarrow, \text { INF- } \gamma \downarrow \\
\text { IL-6 } \downarrow, \text { CD68+ Kupffer cells } \downarrow\end{array}$ & $\begin{array}{l}\text { Activation of NF-кB } \\
\text { signaling pathway } \\
\text { increases iNOS } \\
\text { release }\end{array}$ & $\begin{array}{l}\text { Ye et al. } \\
2019\end{array}$ \\
\hline Adipose & $\begin{array}{l}\text { Transfected with } \\
\text { the IL-35 plasmid }\end{array}$ & N/A & Tail vein & Mice & Con-A & $\begin{array}{c}\mathrm{ALT} \downarrow, \mathrm{AST} \downarrow, \mathrm{IL}-17 \downarrow \\
\text { hepatocytes necrosis and } \\
\text { apoptosis } \downarrow\end{array}$ & $\begin{array}{c}\text { MSCs expressed IL- } \\
\text { 35, activated } \\
\text { Jak1-STAT1/ } \\
\text { STAT4 pathway, and } \\
\text { reduced the secretion } \\
\text { of IFN- } \gamma \text { by } \\
\text { monocytes }\end{array}$ & $\begin{array}{l}\text { Wang et al. } \\
2018\end{array}$ \\
\hline
\end{tabular}

\section{Underlying mechanisms of MSCs therapy}

\section{Trans-differentiation into liver tissue-like cells}

MSCs are malleable and have the potential of trans-differentiation or de-differentiation in response to suitable conditions. Several previous studies have also verified the potential of bone marrow mesenchymal stem cells (BM-MSCs) to differentiate into bone tissue or dedifferentiate and reprogram (Chen et al. 2017, Rui et al. 2015). In addition, several studies have provided evidences that MSCs have the potential to differentiate into hepatocyte-like cells. In 2002, Schwartz et al. firstly discovered that pluripotent adult progenitor cells from humans, rats and mice could be in vitro induced to differentiate into hepatoid cells with functions such as albumin (ALB) secretion, cytochrome $\mathrm{P} 450$ production, low-density lipoprotein absorption and glycogen storage (Schwartz et al. 2002). Later, Lee et al. discovered the potential of BM-MSCs to differentiate into hepatocytelike cells in vitro (Lee et al. 2004). Thus, the differentiation potential of MSCs to various cell types was discovered (Chen et al. 2016, Xu et al. 2017, $\mathrm{Yu}$ et al. 2018). Recently, the efficacy of artificially induced stem cells transplantation has been confirmed, and the trans-differentiation ability of MSCs directly transplanted in animal models of acute liver failure, liver fibrosis, liver cirrhosis as well (Banas et al. 2009, Bruckner et al. 2017, Chen et al. 2016, El Baz et al. 2020, Sato et al. 2005, Zhou et al. 2017). From the results of these systematic studies, we speculate that MSCs can protect the liver through differentiation into hepatocytes.
However, some studies have shown that only a small proportion of stem cells transplanted into animals have undergone trans-differentiation into hepatocytes, suggesting that differentiation of MSCs may not be the main mechanism of their therapy effects (Chen et al. 2017, Dai et al. 2009).

\section{Anti-oxidant stress and tissue damage reduction}

Drugs such as carbon tetrachloride $\left(\mathrm{CCl}_{4}\right)$, dimethylnitrosamine (DMN), and thioacetamide (TAA) are commonly used to construct animal models of liver injury in the laboratory (Cho et al. 2012, Moon et al. 2019). Ischemia-reperfusion injury is also a stable model (Jiao et al. 2020). Exposure of animals to these types of harmful factors stimulated the production a large amount of reactive oxygen species (ROS), which cannot be cleared rapidly, thus inducing oxidative stress. Such conditions lead to tissue necrosis induced acute liver failure, liver fibrosis, liver cirrhosis and other liver pathological changes (Cash et al. 2010, Jiao et al. 2020, Moon et al. 2019, Sabry et al. 2019, Zhang et al. 2020). However, studies have shown that transplantation of MSCs in animal models reduces liver cells injury by increasing superoxide dismutase (SOD) activity and reducing malondialdehyde (MDA) levels (Zheng et al. 2020). Another study by Wan et al. also showed that MSCs exert an antioxidant stress effect in a mouse model of alcoholic hepatitis, resulting in a significant decrease in MDA and a significant increase in glutathione (GSH) in the treatment group (Wan et al. 2020). In addition, Jiao et al. (2020) found that the MSCs derived from adipose 
tissue reduced the endoplasmic reticulum (ER) stress response in Bama miniature pigs and down-regulated the expression of ER stress-related proteins, thereby reducing the tissue injury in the liver. These findings provide evidence that MSCs can reduce oxidative stress and reduce tissue damage.

\section{Exosome-mediated cellular regulation}

Cells can communicate with extracellular vesicles (EVs) through membrane fusion, and the substances contained in these vesicles usually have certain physiological characteristics. The most extensively studied type of vesicles to date is exosome with diameters of 30-100 nm (Gould and Raposo 2013, Raposo and Stoorvogel 2013). Exosomes bud from the endosome system (Cheng et al. 2020) and contain the non-protein coding miRNAs and DNA. When vesicles fuse with the target cell membrane, they may play a protective role in liver tissue by regulating gene expression (Han et al. 2020, Lelek and Zuba-Surma 2020, Valadi et al. 2007, Zhang et al. 2020). In animal models, this process has been shown to suppress immune cells activation and inflammatory factors releasing, promote angiogenesis, reduce liver fibrosis as well as alleviate liver injury (Anger et al. 2019, Fiore et al. 2020, Sabry et al. 2019, Yang et al. 2020). For example, Mardpour et al. investigated the role of exosomes from embryonic MSCs in a rat model of liver cirrhosis. They found that exosome transplantation significantly inhibited the proliferation of mononuclear cells in peripheral blood. Furthermore, the levels of the anti-inflammatory factors transforming growth factor- $\beta$ (TGF- $\beta$ ) and Interleukin-10 (IL-10) were significantly increased, while Interferon- $\gamma$ (IFN- $\gamma$ ) levels decreased, suggesting that exosome transplantation plays a role in inhibiting the inflammatory response. In addition, the changes in the expression of major apoptosis-related genes, caspase-3, B-cell lymphoma 2 (Bcl-2), Bcl-2-associated X protein (BAX); and major fibrosis-related genes, such as $\alpha$ smooth muscle actin ( $\alpha$-SMA), tissue inhibitor of matrix metalloproteinases 1 (TIMP1), matrix metalloproteins 9 (MMP9), matrix metalloprotein 13 (MMP13). These results confirmed the anti-fibrosis and anti-apoptosis effects of exosomes (Mardpour et al. 2018).

Exosomes also contain bioactive substances such as proteins, hormones and cytokines, which can also be transferred between MSCs and target cells to exert regulatory effects (Akyurekli et al. 2015, Baglio et al. 2012). However, exosomes have some disadvantages that limit their clinical application prospects. For example, it has been reported that exosomes may mediate the spread and metastasis of cancer cells and viruses, which requires extra caution in clinical usage (Boelens et al. 2014).

\section{Paracrine and immune regulation}

MSCs secrete many types of soluble factors into the intercellular stroma, and have different effects on target cells. The two main types are nutritional factors, which are involved in the repair and protection of liver tissue from damage, and inflammatory factors, which are involved in the initiation and development of inflammatory responses (Gazdic et al. 2017, Volarevic et al. 2014). However, paracrine regulation is often considered the main mechanism responsible for liver regeneration and protection from inflammatory responses. The nutritional factors secreted by MSCs play an important role in the liver regeneration. Compared with MSCs derived from other tissues, umbilical cord mesenchymal stem cells (UC-MSCs) have significant paracrine characteristics (Hu et al. 2013).

Numerous studies have shown that MSCs secrete a variety of cytokines with multiple functions that form a network (Bai et al. 2016). For example, acid fibroblast growth factor (aFGF), basic fibroblast growth factor (bFGF), insulin-like growth factor (IGF), epidermal growth factor (EGF), vascular endothelial growth factor (VEGF), and Placental growth factor (PLGF), promote angiogenesis (Amable et al. 2014, Liang et al. 2014, Samsonraj et al. 2015). Stromal cellderived factor-1 (SDF-1) and C-X-C chemokine receptor1 (CXCR-1) mediate the migration and homing of MSCs to target tissues (Kim et al. 2011, Samsonraj et al. 2015). Growth factors and nerve growth factors such as hepatocyte growth factor (HGF), granulocyte ColonyStimulating Factor (G-CSF), platelet derived growth factor-AA (PDGF-AA), TGF- $\beta$, and neurotrophin are involved in liver tissue repair (Amable et al. 2014, Banas et al. 2008, Hsieh et al. 2013, Miranda et al. 2015, Shen et al. 2015). In addition, bFGF, HGF, and VEGF showed anti-apoptotic and anti-fibrotic effects (Samsonraj et al. 2015). Thus, it is not difficult to see that the paracrine effect plays an important role in improving liver injury. In addition to nutritional factors that promote liver repair and regeneration, MSCs also secrete cytokines such as TNF- $\alpha$ and other inflammatory factors, which participate in immune regulation and reduce inflammation $(\mathrm{Hu}$ and Li 2019).

MSCs have been shown to reduce inflammatory 
cell infiltration in model animal liver tissues (Fig. 1). In a mouse model of alcoholic hepatitis, Wan et al. found that BM-MSCs reduced the infiltration of neutrophils and macrophages into liver tissues, and decreased the activity of the neutrophil marker myeloperoxidase (MPO) (Wan et al. 2020). Huang et al. obtained similar results in other animal models. In models of fulminant liver failure caused by thioacetamide and liver fibrosis caused by carbon tetrachloride, they found that MSCs and their secreted exosomes reduced the infiltration of hepatic cells. In addition, MSCs also induced the $\mathrm{CD}^{+} \mathrm{T}$ cell system to transform towards an anti-inflammatory phenotype (Huang et al. 2016).

In addition to reducing macrophage infiltration,
MSCs can also inhibit the activation of dendritic cells (DCs), helper T cells, natural killer cells, Kupffer cells and other immune cells by secreting soluble cytokines to avoid the activation of a large-scale inflammatory response when liver tissues are damaged (Hu et al. 2020). Zhang et al. co-cultured TNF- $\alpha$-pretreated MSCs derived exosomes with the RAW264.7 monocytes cell line in vitro and then transplanted the cells into $\mathrm{C} 57 \mathrm{BL} / 6$ male mice with acute liver failure. By inhibiting the activation of the NACHT, LRR, and NOD-like receptor pyrin domain-containing protein 3 (NLRP3) inflammasome, the exosomes alleviated the inflammatory damage induced by macrophages and promoted the repair of liver tissue (Zhang et al. 2020).

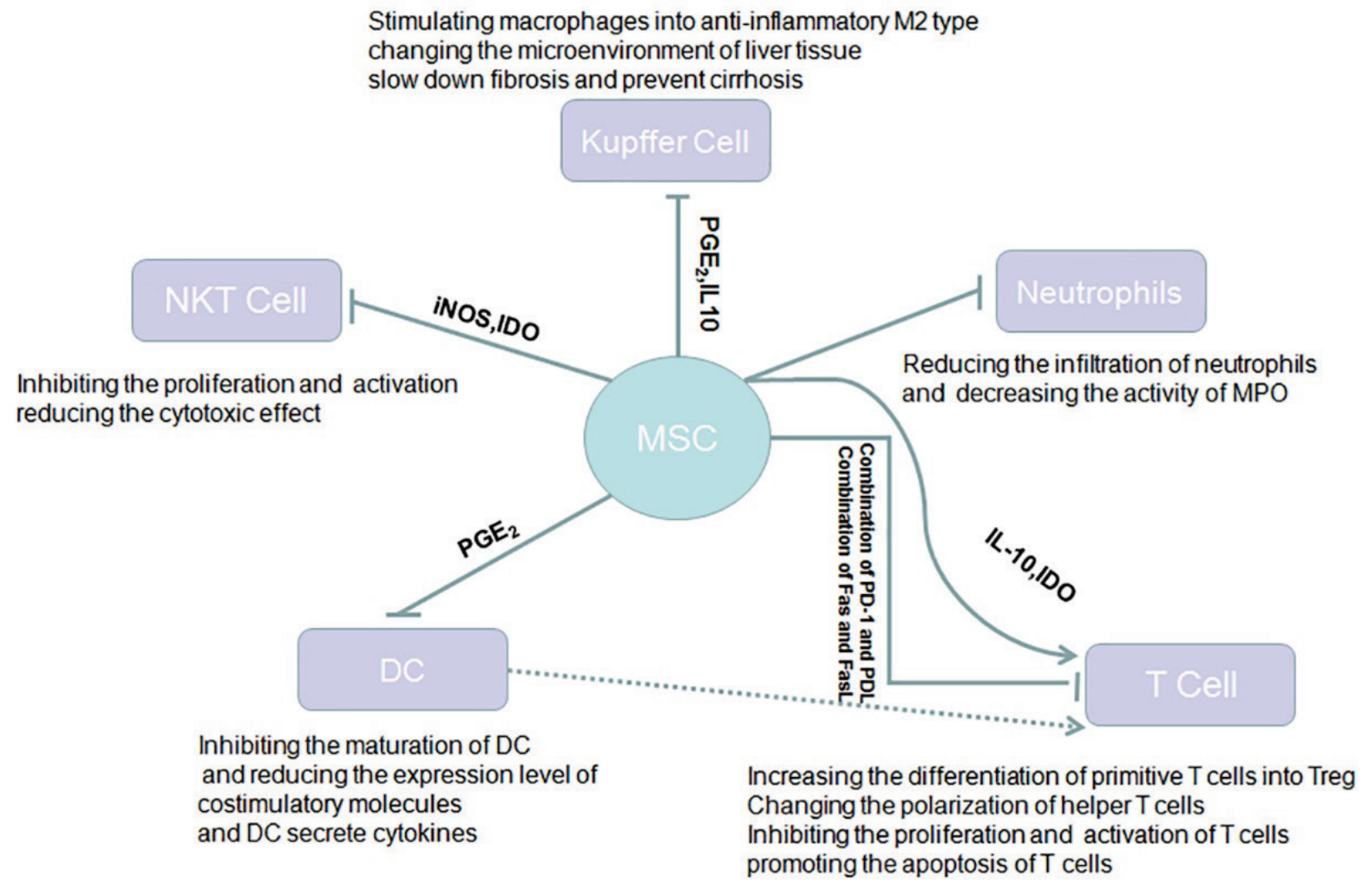

Fig. 1. Mechanisms of MSCs immune regulation functions.

Prostaglandin E2 $\left(\mathrm{PGE}_{2}\right)$ derived from MSCs plays an important role in its immune regulation function. It has been reported that $\mathrm{PGE}_{2}$ can reduce the serum levels of the pro-inflammatory cytokines TNF- $\alpha$, Interleukin-12 (IL-12) and Interleukin-4 (IL-4), and promote the release of the anti-inflammatory cytokine IL-10, thus changing the polarization of helper $\mathrm{T}$ cells and differentiating into anti-inflammatory direction (Sharma et al. 2014). $\mathrm{PGE}_{2}$ also increases the differentiation of primitive $\mathrm{T}$ cells into $\mathrm{CD} 4{ }^{+} \mathrm{CD} 25^{+} \mathrm{Foxp}^{+}$regulatory $\mathrm{T}$ cells, thereby reducing the total number of helper T cells (Volarevic et al. 2011). Studies have also shown that $\mathrm{PGE}_{2}$ may change the microenvironment of liver tissue by stimulating the activation of macrophages into the anti-inflammatory M2 type (Kojima et al. 2019). $\mathrm{PGE}_{2}$ secreted by MSCs can also affect other immune cells, for example, through expressing TNF receptor superfamily, member 6 (Fas) to 
recruit Monocyte chemoattractant protein-1 (MCP-1), a monocyte chemokine, to recruit $\mathrm{T}$ cells, and then promote $\mathrm{T}$ cell apoptosis via Fas ligand (FasL) and inhibit $\mathrm{T}$ cell proliferation (Akiyama et al. 2012). Inhibition of both DC differentiation and the related cytokine secretion leads to $\mathrm{T}$ cell inactivation (Parekkadan et al. 2007, Volarevic et al. 2010, Volarevic et al. 2011).

\section{Strategies to improve the efficacy of MSCs treatment}

\section{Promote homing}

Directional migration to lesions after transplantation is one of mechanisms by which stem cells exert their protective effects on the liver. Therefore, strategies that enhance the recruitment of stem cells and promote their homing to the lesion are potential approaches to improving the efficacy of stem cell transplantation.

Shams et al. showed that HGF and fibro-blast growth factor 4 (FGF4) pretreatment promoted the homing efficiency of MSCs in a carbon tetrachloride mouse model of acute liver fibrosis (Shams et al. 2015). Liu et al. showed that c-Met overexpression in stem cells further reduced the level of serum transaminase, while HGF increased the expression of c-Met and phosphorylated Met, thereby improving the homing efficiency. This finding suggests that the HGF/c-Met signaling pathway plays an important role in promoting the directional migration of MSCs to the liver (Liu et al. 2014). This study further explored the effect of HGF on the homing of MSCs to the liver (Liu et al. 2014). In addition, it has been reported that glycyl tRNA synthetase is released when tissues or cells respond to damage signals, and may have the various beneficial effects, including enhanced the migration of MSCs through its receptor cadherin-6 (CDH-6) (Park et al. 2018).

In addition to the $\mathrm{HGF} / \mathrm{c}-$ Met pathway, the chemokine $\mathrm{C}-\mathrm{X}-\mathrm{C}$ motif receptor4/ chemokine $\mathrm{C}-\mathrm{X}$ $\mathrm{C}$ motif ligand12 (CXCR4/CXCL12) axis is also worthy of our attention in promoting stem cell homing. Stromal cell-derived factor-1, also known as CXCR12, is a cytokine that is believed to have a chemotactic effect on lymphocytes and MSCs (Hajinejad et al. 2018, Jin et al. 2018). Jin et al. reported that SDF-1 level was significantly increased in a mouse liver ischemiareperfusion model. Furthermore, the homing efficiency of MSCs over-expressed SDF-1 was improved under hypoxic pretreatment (Jin et al. 2018). It has also been reported that resveratrol enhanced the homing of BM-MSCs pretreated with SDF-1 $\alpha$ in the rat liver cirrhosis model (Hajinejad et al. 2018).

In a study of a mouse liver ischemia-reperfusion model, Zheng et al. found that rapamycin-induced autophagy enhanced the migration of UC-MSCs to hepatic ischemic areas by upregulating the expression of CXCR4 and CXCR12 in MSCs, while MSCs migration was reduced following inhibition of CXCR4 activation. This finding confirms that CXCR4 plays an important role in the homing process of MSCs from both positive and negative aspects (Zheng et al. 2019).

The migration of stem cells to the lesion is a prerequisite for exerting their various functions and therapeutic effects. However, after transplantation, most stem cells do not migrate in a directional manner, which restricts their efficacy (Rustad and Gurtner 2012). Therefore, these methods of improving the directional migration of MSCs is reliable ways to improve their therapeutic efficacy.

\section{Promote stem cell-dependent liver regeneration}

Stem cell-dependent liver regeneration is not only reflected in the proliferation of MSCs, but also in the MSCs differentiation to hepatic pluripotent stem cells (Kamel et al. 2018, Katselis et al. 2015). Therefore, strategies to promote the differentiation of MSCs into hepatocytes or enhance their ability to induce other stem cells to differentiate into hepatocytes is the key to promoting stem cell-dependent liver regeneration.

$\mathrm{Yu}$ et al. demonstrated that human umbilical cord blood-derived mesenchymal stem cells (HUCBMSCs) have the potential to differentiate into hepatocytelike cells in D-galactosamine/lipopolysaccharide (GalN/LPS) induced liver injury mice and can alleviate liver injury (Yu et al. 2012). Similar results were obtained in by transplantation of HUCB-MSCs in an animal model of liver injury induced by thioamide (KIM et al. 2011).

$\mathrm{Yu}$ et al. made a comparison of the hepatocyte differentiation ability between UC-MSCs and BM-MSCs. RT-qPCR and Western blot analysis showed that the expression levels of hepatocyte specific genes glucose-6 phosphate (G-6P), ALB, cytochrome P450 3A4 (CYP3A4), tyrosine-aminotransferase (TAT), $\alpha 1$ antitrypsin $(\alpha 1 \mathrm{AT})$ in UC-MSCs differentiated cells were higher than BM-MSCs differentiated cells. However, the expression levels of alpha fetoprotein (AFP) were lower. 
These results suggest that UC-MSCs have better differentiation potential. In addition, in the same study, ELISA test showed that within 2-5 weeks, the secretion of ALB and blood urea nitrogen by UC-MSCs was significantly higher than that of BM-MSCs. These results also suggest that UC-MSCs have better differentiation potential (Yu et al. 2018).

HGF is the cytokine that mediates anti-apoptotic effects and promotes mitosis in liver cells, thereby playing an important role in the regeneration and reconstruction of the damaged liver. HGF over-expressed BM-MSCs protected and promoted the proliferation of graft liver in small-for-size liver transplantation model (Yu et al. 2007). Seo et al. reported that UCB-MSCs over-expressing HGF were more effective in treating liver fibrosis in rats than untreated MSCs (Seo et al. 2014). In another study, Chen et al. found that microRNA-26a-5p (miR-26a-5p) inhibits HGF expression. Furthermore, they inhibited miR-26a-5p to promote HGF synthesis and improve the efficacy of BM-MSCs transplantation. This study echoes the observations of Seo et al. on the expression of HGF the transcriptional level (Chen et al. 2017). Previous studies have also shown that HGF plays an important role in the differentiation of MSCs into hepatocytes. Considering the role of HGF in inducing the differentiation of MSCs into hepatocytes and inhibiting hepatocyte apoptosis to promote hepatocyte proliferation, we speculate that treatments or modifications related to high expression of HGF before transplantation of MSCs may be an effective way to promote stem-cell-dependent liver regeneration, and further improve the curative effect on the basis of direct transplantation of MSCs.

Jung et al. found that chorionic-derived MSCs downregulate the methylation of the Interleukin-6/signal transduction and activator of transcription 3 (IL-6/STAT3) promoter region in liver tissue through a paracrine pathway, which promotes activation of IL-6/STAT3 signaling pathway and induces hepatocyte proliferation. However, the paracrine pathway by which MSCs mediates this effect has not yet been elucidated, which suggests that the efficacy of MSCs transplantation can be improved by promoting the paracrine process (Jung et al. 2015).

In summary, the potential of MSCs to differentiate into hepatocytes is dependent on various sources, and the properties of MSCs to promote hepatocyte maturation of other stem cells or dedifferentiated cells (Lysy et al. 2007). MSCs can be induced to differentiate or modified to influence their paracrine regulation pathway or expression of key genes related to liver protection. In this way, the ability of MSCs to promote liver regeneration can be enhanced to improve the therapeutic effect.

\section{Strengthen the immune regulation ability}

The efficacy of MSCs transplantation has been widely confirmed in various animal models. For example, we have previously shown that UC-MSCs can be reprogrammed via in vitro neuronal differentiation and de-differentiation reprogrammed human UC-MSCs, this modification offered therapeutic advantages in inflammatory bowel disease (IBD) treatment via $\mathrm{PGE}_{2}$ dependent $\mathrm{T}$ lymphocyte suppression. Thereby improving the immunosuppressive ability and transplantation efficacy of MSCs (Yang et al. 2018).

Based on the unique immunomodulatory characteristics of MSCs, immune regulation has become the most likely potential mechanism by which MSCs alleviate liver injury and improve liver function. MSCs secrete a variety of cytokines that regulate cytotoxic $\mathrm{T}$ cells, helper T cells, natural killer cells and NKT cells, as well as the function of DCs and other immune effector cells, which in turn, regulate the damage local microenvironment, relieve acute liver failure and control the processes of liver fibrosis and cirrhosis (Fikry et al. 2016, Gazdic et al. 2018, Gazdic et al. 2018, Liang et al. 2018, Qu et al. 2015, Zhang et al. 2014).

DCs are professional antigen presenting cells, which can also affect neighboring lymphocytes through paracrine regulation. Therefore, DCs play a pivotal role in the immune response process. Zhang et al. reported that MSCs successfully recruited DC precursors to the liver, and activated their receptors E-prostanoid 2 (EP2) and E-prostanoid 4 (EP4) through paracrine regulation by $\mathrm{PGE}_{2}$ to phosphorylate downstream phosphoinositide 3-kinase (PI3K) and extracellular signal-regulated kinase $1 / 2$ (ERK1/2), which then induces the differentiation of precursor DCs into regulatory DCs through EP4 and the related PI3K and ERK1/2 signaling pathways (Zhang et al. 2014).

In addition, in this report, MSCs inhibited the activation and migration of $\mathrm{CD} 4^{+} \mathrm{T}$ cells to the liver, resulting in decreased expression of $\mathrm{CD}^{+}$cell-transportrelated chemokines and their receptors, reduced the proportion of helper $\mathrm{T}$ cells, while promoted the differentiation of naïve $\mathrm{T}$ cells into $\mathrm{CD} 4^{+} \mathrm{CD} 25^{+} \mathrm{Foxp}^{+}$ regulatory $\mathrm{T}$ cells, which act as anti-inflammatory $\mathrm{T}$ cells 
against helper $\mathrm{T}$ cells to reduce the intensity of the regulatory immune response, the degree of inflammation and liver injury in the animal model (Zhang et al. 2014). Inflammatory responses can be reduced by promoting regulatory $\mathrm{T}$ cell differentiation and the TGF- $\beta$ and IL-10 secretion, reducing the content of pro-inflammatory factors such as TNF- $\alpha$ and IFN- $\gamma$ in the serum. These findings were in accordance with several other reports showing that MSCs inhibit the function of the different immune cells by activation cytokine secretion (cellular level), the levels of mRNAs (transcription), and concentration of cytokines in liver tissue and serum (translation) to reduce the inflammatory response and improve liver function in model animals (De LunaSaldivar et al. 2019, Duman et al. 2019, Miao et al. 2016, Qu et al. 2015).

Alternatively, Gazdic et al. showed that MSCs decreased the activity of inducible nitric oxide synthase (iNOS) and indoleamine 2,3-dioxygenase (IDO) in NKT cells to decrease their cytotoxicity and improve liver injury (Gazdic et al. 2018). It is interesting to note that other researchers investigated cytotoxic $\mathrm{T}$ cells, Volarevic et al. reported that the loss of cytotoxic T cells by promoting their apoptosis, inhibiting their proliferation and decreasing the expression of CD80 and CD86 molecules enhanced the inhibition of $\mathrm{T}$ cell immune response by reducing the toxicity of cytotoxic T cells (Volarevic et al. 2010, Volarevic et al. 2011). In addition, MSCs can inhibit the polarization of macrophages into the M1-type, increase the M2-type differentiation, and inhibit the release of proinflammatory factors, thereby inhibiting the inflammatory response to reduce liver injury (Liang et al. 2018, Miao et al. 2016).

The immunomodulatory effect of MSCs is not only reflected in the inhibition of the inflammatory response and the reduction of damage, but also in the involvement of MSCs in slowing fibrosis and preventing cirrhosis through the secretion of Interleukin-17 (IL-17), TGF- $\beta$ and other factors. Farouk et al. reported that MSCs down-regulated IL-17A of the IL-6/STAT3 signaling pathway, thus playing an immunomodulatory role in preventing liver fibrosis (Farouk et al. 2018). TGF- $\beta$ not only acts as an anti-inflammatory factor, its role in animal liver fibrosis is also recognized and supported by research findings (De Luna-Saldivar et al. 2019, Radwan and Mohamed 2018).

These studies demonstrated the important role of the immunomodulatory ability of MSCs in protecting the liver and improving liver function. Therefore, pretreatment or modification of MSCs to enhance their immunomodulatory ability represents a potential strategy to improve the efficacy of MSC transplantation in liver injury.

$\mathrm{Gu}$ et al. showed that the deubiquitination enzyme Ubiquitin C-terminal hydrolase 1 (UCHL1) has a negative regulatory effect on the survival and secretion capacity of MSCs. High expression of UCHL1 increased TNF- $\alpha$ and IFN- $\gamma$ while inhibited the secretion of iNOS and IDO. Inhibition of UCHL1 expression improved the therapeutic effect of MSCs in a Concanavalin A (ConA)induced model of liver injury through activation of the nuclear factor kappa-B (NF- $\mathrm{B})$ signal transduction and activator of transcription 1 (STAT1) pathways, enhanced the viability of MSCs via the Bcl-2 gene (Gu et al. 2018). In another study, black algae oil improved the efficacy of MSCs alleviate radiation-induced liver damage. The evaluation indexes of ALT, MDA and SOD in the combined treatment group were all improved when compared with the effects of using black algae oil or MSCs alone. The combination group had the lowest proportion of cells producing TNF- $\alpha$, INF- $\gamma$ and IL-6, and the highest proportion of cells producing IL-10. The trends in the levels of TNF- $\alpha$, INF- $\gamma$, IL- 6 , IL-10, TGF- $\beta$ and other cytokines were consistent with the trends in the proportion of cells producing these factors. This finding confirmed that the treatment with the combination of black algae oil and MSCs improved the inflammatory regulation and liver protection capacities of MSCs (Radwan and Mohamed 2018).

In addition to pretreatment and combined transplantation therapy, MSCs can also be modified to induce over-expression or silencing of certain genes by genetic modification and gene editing. Wang et al. reported that transplantation of stem cells genetically modified to over-express Interleukin-35 (IL-35) significantly reduced the expression of IFN- $\gamma$ via the Janus kinase 1-signal transduction and activator of transcription 1/signal transduction and activator of transcription $4 \quad$ (JAK1-STAT1/STAT4) signaling pathway, and strengthened the immune regulation ability of MSCs. This approach also reduced hepatocyte apoptosis by reducing the expression of FasL on monocytes, which improved the therapeutic efficacy (Wang et al. 2018). In another study, Ye et al. reported that compared with unmodified MSCs, MSCs overexpressing hepatocyte nuclear factor-4 $\alpha$ (HNF-4 $\alpha$ ) increased the expression of iNOS via the signal 
transduction and activation of transcription NF- $\kappa \mathrm{B}$ signaling pathway, thereby enhancing the antiinflammatory effect, and further reducing the expression of IL- 6 , TNF- $\alpha$, and IFN- $\gamma$. At the same time, HNF- $4 \alpha$ over-expression also enhanced the homing of MSCs to the liver, liver regeneration, inhibited the immune response related to $\mathrm{CD} 68^{+} \mathrm{Kupffer}$ cells (Ye et al. 2019). In addition, Choi et al. applied transcription activator-like effector nucleases (TALENS) gene editing to generate MSCs produce IL-10 and these cells showed significantly improved anti-fibrotic and anti-inflammatory abilities, as well as decreased levels of TGF- $\beta$, type I collagen, and matrix metalloprotein 2 (MMP 2) related to liver fibrosis in animal model. The proportion of $\mathrm{CD} 68^{+}$Kupffer cells decreased from $50 \%$ to $25 \%$, and the levels of IL-1, TNF- $\alpha$ and INF- $\gamma$ were further decreased. It was shown that the MSCs expressing IL-10 further reduced the severe inflammatory response, prevented liver fibrosis, and improved liver function (Choi et al. 2019).

By releasing $\mathrm{PGE}_{2}$, IDO and increasing iNOS activity, MSCs can reduce mononuclear macrophage infiltration and inhibit the release of proinflammatory factors, such as TNF- $\alpha$, INF- $\gamma$, IL- 1 and IL-6, meanwhile promote the release of IL-10 and TGF- $\beta$. These factors produced by MSCs can also reduce the cytotoxic effect of cytotoxic T cells, NKT cells and inhibit the function and maturation of DCs to inhibit the inflammatory response and reduce liver injury. Therefore, pretreatment, combined treatment with drugs, gene modification and editing can be applied to promote the immune regulation ability of MSCs, then further enhance their capacity to protect and improve liver function.

\section{Anti-oxidant stress and anti-apoptosis}

Oxidative stress caused by exposure to a large amount of ROS, such as peroxide, superoxide, ozone ions, and oxygen free radicals, is an important mechanism by which acute liver injury is induced. Carbon tetrachloride is a stimulator of oxidative stress in animal model of liver injury induction (Chen et al. 2014). Since MSCs have both anti-oxidative and anti-apoptotic effects, these cells represent a simple and direct approach to reduce apoptosis and protect hepatocytes (Francois et al. 2013, Qi et al. 2018).

The anti-oxidant effects of MSCs on reduction of hepatocyte apoptosis and resistance to liver injury have been investigated in two animal models induced by radiation and carbon tetrachloride (Farouk et al. 2018, Francois et al. 2013, Jiang et al. 2018). Jiang et al. found that transplantation of exosomes from human UC-MSCs improved liver function through their antioxidant potential in animal model. Furthermore, it was shown that exosomes from human UC-MSCs had better effects than the commonly used drug biphenyl diester (Jiang et al. 2018). In the same animal model of liver fibrosis caused by carbon tetrachloride-induced oxidative stress, Shams et al. found that transplantation of MSCs pretreated with FGF and FGF4 resulted in recovery of glycogen storage capacity, and significantly reduced collagen, alkaline phosphatase and bilirubin levels compared with animals that received untreated MSCs. Furthermore, the liver function was restored, the degree of fibrosis decreased, and the level of oxidative stress decreased. In addition, Terminal deoxynucleotidyl transferase-mediated nick end labeling (TUNEL) staining revealed the stronger antiapoptotic ability of the pretreated MSCs. This conclusion was confirmed by qPCR analysis of BAX, BCL-xl and Caspase-3 at the mRNA expression level (Shams et al. 2015). In a similar carbon tetrachloride-induced model of liver injury, Jung promoted IL-6/STAT3 signal transduction by reducing the methylation of the IL-6/SATA3 promoter in MSCs, thus promoting liver cell proliferation and improving the efficacy (Jung et al. 2015).

\section{Conclusions}

Stem cells transplantation has shown promise as an alternative to organ transplantation. MSCs have a wide range of applications in the treatment of liver injury. Definite therapeutic effects have been obtained in animal models of acute liver injury mimicking improper drug use, toxic exposure, chronic persistent hepatitis and fibrosis caused by various pathogen infections and repeated stimulation by adverse factors. However, improvements in the efficacy of MSCs transplantation are required to ensure this approach can be widely applied in clinical practice. Modification of MSCs is a simple and feasible approach to enhancing their therapeutic potential prior to transplantation.

At present, the modifications to enhance the therapeutic effect of MSCs in liver diseases have four major purposes: strengthening homing ability, promoting regeneration, improving immune regulation ability and protecting liver cells. These strategies have yielded some promising results in animal models. In particular, the immune regulation ability of MSCs to protect liver tissue and inhibit the progression of fibrosis has received most 
attention. However, we have not yet defined a complete and accurate scheme that can be used to precisely correspond with the mechanism by which the therapeutic effect of MSCs can be improved. Moreover, the clinical effects of MSCs after in vitro stimulation or genetic modification have not yet been systematic identified, and the safety of their usage must be confirmed. Therefore, further investigations are required not only to improve the efficacy of MSCs, but also to translate the modified cells into clinical applications.

\section{Conflict of Interest}

There is no conflict of interest.

\section{Acknowledgements}

This study was supported by the Science and Technology Research Project of Hubei Provincial Department of Education Q20191312 and the Joint Fund of the Hubei Provincial Commission of Health and Family Planning WJ2018H190.

\section{Abbreviations}

aFGF - acid fibroblast growth factor, ALB - albumin, AFP - alpha fetoprotein, bFGF - basic fibroblast growth factor, Bcl-2 - B-cell lymphoma 2, BAX - Bcl-2associated $\mathrm{X}$ protein, BM-MSCs - bone marrow mesenchymal stem cells, CDH-6 - cadherin-6, ConA Concanavalin A, CXCR-1 - C-X-C chemokine receptor1, CXCL12 - C-X-C motif ligand12, CXCR4 - C-X-C motif receptor4, CYP3A4 - cytochrome P450 3A4, DCs - dendritic cells, GalN - D-galactosamine, DMN dimethylnitrosamine, ER - endoplasmic reticulum, ERK1/2 - extracellular signal-regulated kinase 1/2, EVs - extracellular vesicles, FasL - Fas ligand, FGF4 - fibroblast growth factor 4, G-6P - glucose-6phosphate, GSH glutathione, G-CSF - granulocyte Colony-Stimulating
Factor, HGF - hepatocyte growth factor, HNF-4 $\alpha$ hepatocyte nuclear factor-4 $\alpha$, HUCB-MSCs - human umbilical cord blood-derived mesenchymal stem cells, IDO - indoleamine 2,3-dioxygenase, iNOS - inducible nitric oxide synthase, IBD - inflammatory bowel disease, IFN- $\gamma$ - Interferon- $\gamma$, IL-1 - Interleukin-1, IL-10 Interleukin-10, IL-12 - Interleukin-12, IL-17 Interleukin-17, IL-35 - Interleukin-35, IL-4 - Interleukin4, IL-6 - Interleukin-6, JAK1 - Janus kinase 1, LPS lipopolysaccharide, MDA - malondialdehyde, MMP13 matrix metalloprotein 13, MMP 2 - matrix metalloprotein 2, MMP9 - matrix metalloprotein 9, MCP-1 - Monocyte chemoattractant protein-1, MPO - myeloperoxidase, MSCs - mesenchymal stem cells, NKT - Natural killer T cell, NLRP3 - NOD-like receptor pyrin domaincontaining protein $3, \mathrm{NF}-\kappa \mathrm{B}$ - nuclear factor kappa-B, PI3K - phosphorylate downstream phosphoinositide 3-kinase, PLGF - Placental growth factor, PDGF-AA platelet derived growth factor-AA, PGE2 - Prostaglandin E2, ROS - reactive oxygen species, STAT1 - signal transduction and activator of transcription 1, STAT3 signal transduction and activator of transcription 3 , STAT4 - signal transduction and activator of transcription 4, SDF-1 - Stromal cell-derived factor-1, SOD - superoxide dismutase, TUNEL - Terminal deoxynucleotidyl transferase-mediated nick end labeling, TAA - thioacetamide, TIMP1 - tissue inhibitor of matrix metalloproteinases 1, Fas - TNF receptor superfamily, member 6, TALENS - transcription activator-like effector nucleases, TGF- $\beta$ - transforming growth factor$\beta$, TAT - tryosine-aminotransferase, TNF- $\alpha$ - tumor necrosis factor $\alpha$, UCHL1 - Ubiquitin C-terminal hydrolase 1, UC-MSCs - umbilical cord mesenchymal stem cells, VEGF - vascular endothelial growth factor, $\alpha$-SMA $-\alpha$ smooth muscle actin, $\alpha 1$ AT $-\alpha 1$ antitrypsin.

\section{References}

AKIYAMA K, CHEN C, WANG D, XU X, QU C, YAMAZA T, CAI T, CHEN W, SUN L, SHI S: Mesenchymalstem-cell-induced immunoregulation involves FAS-ligand-/FAS-mediated T cell apoptosis. Cell Stem Cell 10: 544-555, 2012. https://doi.org/10.1016/j.stem.2012.03.007

AKYUREKLI C, LE Y, RICHARDSON RB, FERGUSSON D, TAY J, ALLAN DS: A systematic review of preclinical studies on the therapeutic potential of mesenchymal stromal cell-derived microvesicles. Stem Cell Rev Rep 11: 150-160, 2015. https://doi.org/10.1007/s12015-014-9545-9

AMABLE PR, TEIXEIRA MV, CARIAS RB, GRANJEIRO JM, BOROJEVIC R: Protein synthesis and secretion in human mesenchymal cells derived from bone marrow, adipose tissue and Wharton's jelly. Stem Cell Res Ther 5: 53, 2014. https://doi.org/10.1186/scrt442 
ANGER F, CAMARA M, ELLINGER E, GERMER CT, SCHLEGEL N, OTTO C, KLEIN I: Human mesenchymal stromal cell-derived extracellular vesicles improve liver regeneration after ischemia reperfusion injury in mice. Stem Cells Dev 28: 1451-1462, 2019. https://doi.org/10.1089/scd.2019.0085

BAGLIO SR, PEGTEL DM, BALDINI N: Mesenchymal stem cell secreted vesicles provide novel opportunities in (stem) cell-free therapy. Front Physiol 3: 359, 2012. https://doi.org/10.3389/fphys.2012.00359

BAI L, LI D, LI J, LUO Z, YU S, CAO S, SHEN L, ZUO Z, MA X: Bioactive molecules derived from umbilical cord mesenchymal stem cells. Acta Histochem 118: 761-769, 2016. https://doi.org/10.1016/j.acthis.2016.09.006

BANAS A, TERATANI T, YAMAMOTO Y, TOKUHARA M, TAKESHITA F, OSAKI M, KATO T, OKOCHI H, OCHIYA T: Rapid hepatic fate specification of adipose-derived stem cells and their therapeutic potential for liver failure. J Gastroenterol Hepatol 24: 70-77, 2009. https://doi.org/10.1111/j.1440-1746.2008.05496.x

BANAS A, TERATANI T, YAMAMOTO Y, TOKUHARA M, TAKESHITA F, OSAKI M, KAWAMATA M, KATO T, OKOCHI H, OCHIYA T: IFATS collection: in vivo therapeutic potential of human adipose tissue mesenchymal stem cells after transplantation into mice with liver injury. Stem Cells 26: 2705-2712, 2008. https://doi.org/10.1634/stemcells.2008-0034

BOELENS MC, WU TJ, NABET BY, XU B, QIU Y, YOON T, AZZAM DJ, TWYMAN-SAINT VICTOR C, WIEMANN BZ, ISHWARAN H, TER BRUGGE PJ, JONKERS J, SLINGERLAND J, MINN AJ: Exosome transfer from stromal to breast cancer cells regulates therapy resistance pathways. Cell 159: 499-513, 2014. https://doi.org/10.1016/j.cell.2014.09.051

BOYD A, NEWSOME P, LU WY: The role of stem cells in liver injury and repair. Expert Rev Gastroenterol Hepatol 13: 623-631, 2019. https://doi.org/10.1080/17474124.2019.1618186

BRUCKNER S, ZIPPRICH A, HEMPEL M, THONIG A, SCHWILL F, RODERFELD M, ROEB E, CHRIST B: Improvement of portal venous pressure in cirrhotic rat livers by systemic treatment with adipose tissue-derived mesenchymal stromal cells. Cytotherapy 19: 1462-1473, 2017. https://doi.org/10.1016/j.jcyt.2017.09.006

CASH WJ, MCCANCE DR, YOUNG IS, MCENENY J, CADDEN IS, MCDOUGALL NI, CALLENDER ME: Primary biliary cirrhosis is associated with oxidative stress and endothelial dysfunction but not increased cardiovascular risk. Hepatol Res 40: 1098-1106, 2010. https://doi.org/10.1111/j.1872-034X.2010.00717.X

CHEN L, ZENG W, YANG B, CUI X, FENG C, WANG L, WANG H, ZHOU X, LI P, LV F, LI T: Expression of antisense of microRNA-26a-5p in mesenchymal stem cells increases their therapeutic effects against cirrhosis. Am J Transl Res 9: 1500-1508, 2017.

CHEN L, ZHANG C, CHEN L, WANG X, XIANG B, WU X, GUO Y, MOU X, YUAN L, CHEN B, WANG J, XIANG $\mathrm{C}$ : Human menstrual blood-derived stem cells ameliorate liver fibrosis in mice by targeting hepatic stellate cells via paracrine mediators. Stem Cells Transl Med 6: 272-284, 2017. https://doi.org/10.5966/sctm.2015-0265

CHEN M, HUANG W, WANG C, NIE H, LI G, SUN T, YANG F, ZHANG Y, SHU K, WANG C, GONG Q: Highmobility group box 1 exacerbates $\mathrm{CCl}(4)$-induced acute liver injury in mice. Clin Immunol 153: 56-63, 2014. https://doi.org/10.1016/j.clim.2014.03.021

CHEN R, LEE WY, ZHANG XH, ZHANG JT, LIN S, XU LL, HUANG B, YANG FY, LIU HL, WANG B, TSANG LL, WILLAIME-MORAWEK S, LI G, CHAN HC, JIANG X: Epigenetic modification of the CCL5/CCR1/ERK axis enhances glioma targeting in dedifferentiation-reprogrammed BMSCs. Stem Cell Reports 8: 743-757, 2017. https://doi.org/10.1016/j.stemcr.2017.01.016

CHEN Z, KUANG Q, LAO XJ, YANG J, HUANG W, ZHOU D: Differentiation of UC-MSCs into hepatocyte-like cells in partially hepatectomized model rats. Exp Ther Med 12: 1775-1779, 2016. https://doi.org/10.3892/etm.2016.3543

CHENG Y, CAO X, QIN L: Mesenchymal stem cell-derived extracellular vesicles: A novel cell-free therapy for sepsis. Front Immunol 11: 647, 2020. https://doi.org/10.3389/fimmu.2020.00647

CHO KA, WOO SY, SEOH JY, HAN HS, RYU KH: Mesenchymal stem cells restore CCl4-induced liver injury by an antioxidative process. Cell Biol Int 36: 1267-1274, 2012. https://doi.org/10.1042/CBI20110634

CHOI JS, JEONG IS, HAN JH, CHEON SH, KIM SW: IL-10-secreting human MSCs generated by TALEN gene editing ameliorate liver fibrosis through enhanced anti-fibrotic activity. Biomater Sci 7: 1078-1087, 2019. https://doi.org/10.1039/C8BM01347K

DAI LJ, LI HY, GUAN LX, RITCHIE G, ZHOU JX: The therapeutic potential of bone marrow-derived mesenchymal stem cells on hepatic cirrhosis. Stem Cell Res 2: 16-25, 2009. https://doi.org/10.1016/j.scr.2008.07.005 
DE LUNA-SALDIVAR MM, MARINO-MARTINEZ IA, FRANCO-MOLINA MA, RIVERA-MORALES LG, ALARCON-GALVAN G, CORDERO-PEREZ P, ROJAS-MARTINEZ A, RODRIGUEZ-PADILLA C, MUNOZ-ESPINOSA LE: Advantages of adipose tissue stem cells over CD34(+) mobilization to decrease hepatic fibrosis in Wistar rats. Ann Hepatol 18: 620-626, 2019. https://doi.org/10.1016/j.aohep.2018.12.005

DUMAN DG, ZIBANDEH N, UGURLU MU, CELIKEL C, AKKOC T, BANZRAGCH M, GENC D, OZDOGAN O, AKKOC T: Mesenchymal stem cells suppress hepatic fibrosis accompanied by expanded intrahepatic natural killer cells in rat fibrosis model. Mol Biol Rep 46: 2997-3008, 2019. https://doi.org/10.1007/s11033-019-04736-4

EL BAZ H, DEMERDASH Z, KAMEL M, HAMMAM O, SAMIR ABDELHADY D, MAHMOUD S, HASSAN S, MAHMOUD F, ATTA S, RIAD NM, GAAFAR T: Induction of hepatic regeneration in an experimental model using hepatocyte-differentiated mesenchymal stem cells. Cell Reprogram 22: 2020. https://doi.org/10.1089/cell.2019.0076

EOM YW, SHIM KY, BAIK SK: Mesenchymal stem cell therapy for liver fibrosis. Korean J Intern Med 30: 580-589, 2015. https://doi.org/10.3904/kjim.2015.30.5.580

FAROUK S, SABET S, ABU ZAHRA FA, EL-GHOR AA: Bone marrow derived-mesenchymal stem cells downregulate IL17A dependent IL6/STAT3 signaling pathway in CCl4-induced rat liver fibrosis. PLoS One 13: e0206130, 2018. https://doi.org/10.1371/journal.pone.0206130

FATHI E, FARAHZADI R, SHEIKHZADEH N: Immunophenotypic characterization, multi-lineage differentiation and aging of zebrafish heart and liver tissue-derived mesenchymal stem cells as a novel approach in stem cellbased therapy. Tissue Cell 57: 15-21, 2019. https://doi.org/10.1016/j.tice.2019.01.006

FIKRY H, GAWAD SA, BAHER W: Therapeutic potential of bone marrow-derived mesenchymal stem cells on experimental liver injury induced by Schistosoma mansoni: A histological study. Int J Stem Cells 9: 96-106, 2016. https://doi.org/10.15283/ijsc.2016.9.1.96

FIORE E, DOMINGUEZ LM, BAYO J, MALVICINI M, ATORRASAGASTI C, RODRIGUEZ M, CANTERO MJ, GARCIA M, YANNARELLI G, MAZZOLINI G: Human umbilical cord perivascular cells-derived extracellular vesicles mediate the transfer of IGF-I to the liver and ameliorate hepatic fibrogenesis in mice. Gene Ther 27: 62-73, 2020. https://doi.org/10.1038/s41434-019-0102-7

FRANCOIS S, MOUISEDDINE M, ALLENET-LEPAGE B, VOSWINKEL J, DOUAY L, BENDERITTER M, CHAPEL A: Human mesenchymal stem cells provide protection against radiation-induced liver injury by antioxidative process, vasculature protection, hepatocyte differentiation, and trophic effects. Biomed Res Int 2013: 151679, 2013. https://doi.org/10.1155/2013/151679

GAZDIC M, ARSENIJEVIC A, MARKOVIC BS, VOLAREVIC A, DIMOVA I, DJONOV V, ARSENIJEVIC N, STOJKOVIC M, VOLAREVIC V: Mesenchymal stem cell-dependent modulation of liver diseases. Int J Biol Sci 13: 1109-1117, 2017. https://doi.org/10.7150/ijbs.20240

GAZDIC M, MARKOVIC BS, ARSENIJEVIC A, JOVICIC N, ACOVIC A, HARRELL CR, FELLABAUM C, DJONOV V, ARSENIJEVIC N, LUKIC ML, VOLAREVIC V: Crosstalk between mesenchymal stem cells and $\mathrm{T}$ regulatory cells is crucially important for the attenuation of acute liver injury. Liver Transpl 24: 687-702, 2018. https://doi.org/10.1002/1t.25049

GAZDIC M, SIMOVIC MARKOVIC B, VUCICEVIC L, NIKOLIC T, DJONOV V, ARSENIJEVIC N, TRAJKOVIC V, LUKIC ML, VOLAREVIC V: Mesenchymal stem cells protect from acute liver injury by attenuating hepatotoxicity of liver natural killer $\mathrm{T}$ cells in an inducible nitric oxide synthase- and indoleamine 2,3-dioxygenase-dependent manner. J Tissue Eng Regen Med 12: e1173-e1185, 2018. https://doi.org/10.1002/term.2452

GOULD SJ, RAPOSO G: As we wait: coping with an imperfect nomenclature for extracellular vesicles. J Extracell Vesicles 2: 2013. https://doi.org/10.3402/jev.v2i0.20389

GU Y, DING X, HUANG J, XUE M, ZHANG J, WANG Q, YU H, WANG Y, ZHAO F, WANG H, JIN M, WU Y, ZHANG Y: The deubiquitinating enzyme UCHL1 negatively regulates the immunosuppressive capacity and survival of multipotent mesenchymal stromal cells. Cell Death Dis 9: 459, 2018. https://doi.org/10.1038/s41419-018-0532-y

HAJINEJAD M, PASBAKHSH P, OMIDI A, MORTEZAEE K, NEKOONAM S, MAHMOUDI R, KASHANI IR: Resveratrol pretreatment enhanced homing of SDF-1alpha-preconditioned bone marrow-derived mesenchymal stem cells in a rat model of liver cirrhosis. J Cell Biochem 119: 2939-2950, 2018. https://doi.org/10.1002/jcb.26500 
HAN HS, LEE H, YOU D, NGUYEN VQ, SONG DG, OH BH, SHIN S, CHOI JS, KIM JD, PAN CH, JO DG, CHO YW, CHOI KY, PARK JH: Human adipose stem cell-derived extracellular nanovesicles for treatment of chronic liver fibrosis. J Control Release 320: 328-336, 2020. https://doi.org/10.1016/j.jconrel.2020.01.042

HSIEH JY, WANG HW, CHANG SJ, LIAO KH, LEE IH, LIN WS, WU CH, LIN WY, CHENG SM: Mesenchymal stem cells from human umbilical cord express preferentially secreted factors related to neuroprotection, neurogenesis, and angiogenesis. PLoS One 8: e72604, 2013. https://doi.org/10.1371/journal.pone.0072604

HU C, LI L: The immunoregulation of mesenchymal stem cells plays a critical role in improving the prognosis of liver transplantation. J Transl Med 17: 412, 2019. https://doi.org/10.1186/s12967-019-02167-0

HU C, WU Z, LI L: Mesenchymal stromal cells promote liver regeneration through regulation of immune cells. Int J Biol Sci 16: 893-903, 2020. https://doi.org/10.7150/ijbs.39725

HU C, ZHAO L, DUAN J, LI L: Strategies to improve the efficiency of mesenchymal stem cell transplantation for reversal of liver fibrosis. J Cell Mol Med 23: 1657-1670, 2019. https://doi.org/10.1111/jcmm.14115

HU C, ZHAO L, WU Z, LI L: Transplantation of mesenchymal stem cells and their derivatives effectively promotes liver regeneration to attenuate acetaminophen-induced liver injury. Stem Cell Res Ther 11: 88, 2020. https://doi.org/10.1186/s13287-020-01596-9

HU L, HU J, ZHAO J, LIU J, OUYANG W, YANG C, GONG N, DU L, KHANAL A, CHEN L: Side-by-side comparison of the biological characteristics of human umbilical cord and adipose tissue-derived mesenchymal stem cells. Biomed Res Int 2013: 438243, 2013. https://doi.org/10.1155/2013/438243

HUANG B, CHENG X, WANG H, HUANG W, LA GA HU Z, WANG D, ZHANG K, ZHANG H, XUE Z, DA Y, ZHANG N, HU Y, YAO Z, QIAO L, GAO F, ZHANG R: Mesenchymal stem cells and their secreted molecules predominantly ameliorate fulminant hepatic failure and chronic liver fibrosis in mice respectively. J Translat Med 14: 45, 2016. https://doi.org/10.1186/s12967-016-0792-1

JIANG W, TAN Y, CAI M, ZHAO T, MAO F, ZHANG X, XU W, YAN Z, QIAN H, YAN Y: Human umbilical cord MSC-derived exosomes suppress the development of CCl4-induced liver injury through antioxidant effect. Stem Cells Int 2018: 6079642, 2018. https://doi.org/10.1155/2018/6079642

JIAO Z, LIU X, MA Y, GE Y, ZHANG Q, LIU B, WANG H: Adipose-derived stem cells protect ischemia-reperfusion and partial hepatectomy by attenuating endoplasmic reticulum stress. Front Cell Dev Biol 8: 177, 2020. https://doi.org/10.3389/fcell.2020.00177

JIN W, LIANG X, BROOKS A, FUTREGA K, LIU X, DORAN MR, SIMPSON MJ, ROBERTS MS, WANG H: Modelling of the SDF-1/CXCR4 regulated in vivo homing of therapeutic mesenchymal stem/stromal cells in mice. PeerJ 6: e6072, 2018. https://doi.org/10.7717/peerj.6072

JUNG J, MOON JW, CHOI JH, LEE YW, PARK SH, KIM GJ: Epigenetic alterations of IL-6/STAT3 signaling by placental stem cells promote hepatic regeneration in a rat model with CCl4-induced liver injury. Int J Stem Cells 8: 79-89, 2015. https://doi.org/10.15283/ijsc.2015.8.1.79

KAMEL MM, BAZ HGE, DEMERDASH Z, HASSAN S, SALAH F, MANSOUR WA, HAMMAM O, ATTA S, BAYOUMI A, HASSAN M, MAHMOUD S: Cord blood-derived mesenchymal stem cells with hepatogenic differentiation potential ameliorate chronic liver affection in experimental models. Adv Clin Exp Med 27: 1329-1339, 2018. https://doi.org/10.17219/acem/70430

KATSELIS C, APOSTOLOU K, FERETIS T, PAPANIKOLAOU IG, ZOGRAFOS GC, TOUTOUZAS K, PAPALOIS A: Role of stem cells transplantation in tissue regeneration after acute or chronic acetaminophen induced liver injury. J Inv Surg 29: 112-120, 2015. https://doi.org/10.3109/08941939.2015.1086040

KIM S, KIM H-S, LEE E, KIM HO: In vivo hepatic differentiation potential of human cord blood-derived mesenchymal stem cells. Int J Mol Med 27: 701-706, 2011. https://doi.org/10.3892/ijmm.2011.627

KIM SM, KIM DS, JEONG CH, KIM DH, KIM JH, JEON HB, KWON SJ, JEUN SS, YANG YS, OH W, CHANG JW: CXC chemokine receptor 1 enhances the ability of human umbilical cord blood-derived mesenchymal stem cells to migrate toward gliomas. Biochem Biophys Res Commun 407: 741-746, 2011. https://doi.org/10.1016/j.bbrc.2011.03.093

KLADNICKÁ I, ČEDÍKOVÁ M, KRIPNEROVÁ M, DVOŘÁKOVÁ J, KOHOUTOVÁ M, TƯMA Z, MÜLLEROVÁ D, KUNCOVÁ J: Mitochondrial respiration of adipocytes differentiating from human mesenchymal stem cells derived from adipose tissue. Physiol Res 68 (Suppl 3): S287-S296, 2019. https://doi.org/10.33549/physiolres. 934353 
KOJIMA Y, TSUCHIYA A, OGAWA M, NOJIRI S, TAKEUCHI S, WATANABE T, NAKAJIMA K, HARA Y, YAMASHITA J, KIKUTA J, TAKAMURA M, ISHII M, TERAI S: Mesenchymal stem cells cultured under hypoxic conditions had a greater therapeutic effect on mice with liver cirrhosis compared to those cultured under normal oxygen conditions. Regen Ther 11: 269-281, 2019. https://doi.org/10.1016/j.reth.2019.08.005

LEE KD, KUO TK, WHANG-PENG J, CHUNG YF, LIN CT, CHOU SH, CHEN JR, CHEN YP, LEE OK: In vitro hepatic differentiation of human mesenchymal stem cells. Hepatology 40: 1275-1284, 2004. https://doi.org/10.1002/hep.20469

LELEK J, ZUBA-SURMA EK: Perspectives for future use of extracellular vesicles from umbilical cord- and adipose tissue-derived mesenchymal stem/stromal cells in regenerative therapies-synthetic review. Int J Mol Sci 21: 799, 2020. https://doi.org/10.3390/ijms21030799

LIANG X, DING Y, ZHANG Y, TSE HF, LIAN Q: Paracrine mechanisms of mesenchymal stem cell-based therapy: current status and perspectives. Cell Transplant 23: 1045-1059, 2014. https://doi.org/10.3727/096368913X667709

LIANG X, LI T, ZHOU Q, PI S, LI Y, CHEN X, WENG Z, LI H, ZHAO Y, WANG H, CHEN Y: Mesenchymal stem cells attenuate sepsis-induced liver injury via inhibiting M1 polarization of Kupffer cells. Mol Cell Biochem 452: 187-197, 2018. https://doi.org/10.1007/s11010-018-3424-7

LIU J, PAN G, LIANG T, HUANG P: HGF/c-Met signaling mediated mesenchymal stem cell-induced liver recovery in intestinal ischemia reperfusion model. Int J Med Sci 11: 626-633, 2014. https://doi.org/10.7150/ijms.8228

LOU G, CHEN Z, ZHENG M, LIU Y: Mesenchymal stem cell-derived exosomes as a new therapeutic strategy for liver diseases. Exp Mol Med 49: e346, 2017. https://doi.org/10.1038/emm.2017.63

LU C, FENG Y, SUN X, LI N, KUANG D, WANG W, TONG P, HAN Y, XIA X, DAI J: Tree shrew bone marrowderived mesenchymal stem cells express CD81, OCLN, and miR-122, facilitating the entire hepatitis C virus life cycle. J Med Virol 92: 3465-3474, 2020. https://doi.org/10.1002/jmv.25710

LYSY PA, SMETS F, SIBILLE C, NAJIMI M, SOKAL EM: Human skin fibroblasts: From mesodermal to hepatocytelike differentiation. Hepatology 46: 1574-1585, 2007. https://doi.org/10.1002/hep.21839

MARDPOUR S, HASSANI SN, MARDPOUR S, SAYAHPOUR F, VOSOUGH M, AIJ, AGHDAMI N, HAMIDIEH AA, BAHARVAND H: Extracellular vesicles derived from human embryonic stem cell-MSCs ameliorate cirrhosis in thioacetamide-induced chronic liver injury. J Cell Physiol 233: 9330-9344, 2018. https://doi.org/10.1002/jcp.26413

MIAO CM, JIANG XW, HE K, LI P Z, LIU ZJ, CAO D, OU ZB, GONG JP, LIU CA, CHENG Y: Bone marrow stromal cells attenuate LPS-induced mouse acute liver injury via the prostaglandin E 2-dependent repression of the NLRP3 inflammasome in Kupffer cells. Immunol Lett 179: 102-113, 2016. https://doi.org/10.1016/j.imlet.2016.09.009

MIRANDA JP, FILIPE E, FERNANDES AS, ALMEIDA JM, MARTINS JP, DE LA FUENTE A, ABAL M, BARCIA RN, CRUZ P, CRUZ H, CASTRO M, SANTOS JM: The human umbilical cord tissue-derived MSC population $\mathrm{UCX}((\mathrm{R}))$ promotes early motogenic effects on keratinocytes and fibroblasts and G-CSF-mediated mobilization of BM-MSCs when transplanted in vivo. Cell Transplant 24: 865-877, 2015. https://doi.org/10.3727/096368913X676231

MOON SH, LEE CM, PARK S-H, JIN NAM M: Effects of hepatocyte growth factor gene-transfected mesenchymal stem cells on dimethylnitrosamine-induced liver fibrosis in rats. Growth Factors 37: 105-119, 2019. https://doi.org/10.1080/08977194.2019.1652399

PAREKKADAN B, VAN POLL D, SUGANUMA K, CARTER EA, BERTHIAUME F, TILLES AW, YARMUSH ML: Mesenchymal stem cell-derived molecules reverse fulminant hepatic failure. PLoS One 2: e941, 2007. https://doi.org/10.1371/journal.pone.0000941

PARK SR, KIM HJ, YANG SR, PARK CH, LEE HY, HONG IS: A novel endogenous damage signal, glycyl tRNA synthetase, activates multiple beneficial functions of mesenchymal stem cells. Cell Death Differ 25: 2023-2036, 2018. https://doi.org/10.1038/s41418-018-0099-2

PUGLISI MA, TESORI V, LATTANZI W, PISCAGLIA AC, GASBARRINI GB, D'UGO DM, GASBARRINI A: Therapeutic implications of mesenchymal stem cells in liver injury. J Biomed Biotechnol 2011: 860578, 2011. https://doi.org/10.1155/2011/860578 
PYTLÍK R, RENTSCH C, SOUKUP T, NOVOTNÝ L, RENTSCH B, KANDEROVÁ V, RYCHTRMOCOVÁ H, KALMÁROVÁ M, STEHLÍK D, TRNĚNÝ M, SLANAŘ O: Efficacy and safety of human mesenchymal stromal cells in healing of critical-size bone defects in immunodeficient rats. Physiol Res 66: 113-123, 2017. https://doi.org/10.33549/physiolres.933376

QI X, NG KT-P, LIAN Q, LI CX, GENG W, LING CC, YEUNG WH, MA YY, LIU XB, LIU H, LIU J, YANG XX, LO CM, MAN K: Glutathione peroxidase 3 delivered by hiPSC-MSCs ameliorated hepatic IR injury via inhibition of hepatic senescence. Theranostics 8: 212-222, 2018. https://doi.org/10.7150/thno.21656

QU M, CUI J, ZHU J, MA Y, YUAN X, SHI J, GUO D, LI C: Bone marrow-derived mesenchymal stem cells suppress NK cell recruitment and activation in PolyI:C-induced liver injury. Biochem Biophys Res Commun 466: 173-179, 2015. https://doi.org/10.1016/j.bbrc.2015.08.125

RADWAN RR, MOHAMED HA: Nigella sativa oil modulates the therapeutic efficacy of mesenchymal stem cells against liver injury in irradiated rats. J Photochem Photobiol B 178: 447-456, 2018. https://doi.org/10.1016/j.jphotobiol.2017.11.037

RAPOSO G, STOORVOGEL W: Extracellular vesicles: exosomes, microvesicles, and friends. J Cell Biol 200: 373-383, 2013. https://doi.org/10.1083/jcb.201211138

RUI Y, XU L, CHEN R, ZHANG T, LIN S, HOU Y, LIU Y, MENG F, LIU Z, NI M, TSANG KS, YANG F, WANG C, CHAN HC, JIANG X, LI G: Epigenetic memory gained by priming with osteogenic induction medium improves osteogenesis and other properties of mesenchymal stem cells. Sci Rep 5: 11056, 2015. https://doi.org/10.1038/srep11056

RUSTAD KC, GURTNER GC: Mesenchymal stem cells home to sites of injury and inflammation. Adv Wound Care (New Rochelle) 1: 147-152, 2012. https://doi.org/10.1089/wound.2011.0314

SABRY D, MOHAMED A, MONIR M, IBRAHIM HA: The effect of mesenchymal stem cells derived microvesicles on the treatment of experimental CCL4 induced liver fibrosis in rats. Int J Stem Cells 12: 400-409, 2019. https://doi.org/10.15283/ijsc18143

SAMSONRAJ RM, RAI B, SATHIYANATHAN P, PUAN KJ, ROTZSCHKE O, HUI JH, RAGHUNATH M, STANTON LW, NURCOMBE V, COOL SM: Establishing criteria for human mesenchymal stem cell potency. Stem Cells 33: 1878-1891, 2015. https://doi.org/10.1002/stem.1982

SATO Y, ARAKI H, KATO J, NAKAMURA K, KAWANO Y, KOBUNE M, SATO T, MIYANISHI K, TAKAYAMA T, TAKAHASHI M, TAKIMOTO R, IYAMA S, MATSUNAGA T, OHTANI S, MATSUURA A, HAMADA H, NIITSU Y: Human mesenchymal stem cells xenografted directly to rat liver are differentiated into human hepatocytes without fusion. Blood 106: 756-763, 2005. https://doi.org/10.1182/blood-2005-02-0572

SCHWARTZ RE, REYES M, KOODIE L, JIANG Y, BLACKSTAD M, LUND T, LENVIK T, JOHNSON S, HU W-S, VERFAILLIE CM: Multipotent adult progenitor cells from bone marrow differentiate into functional hepatocyte-like cells. J Clin Invest 109: 1291-1302, 2002. https://doi.org/10.1172/JCI0215182

SEO KW, SOHN SY, BHANG DH, NAM MJ, LEE HW, YOUN HY: Therapeutic effects of hepatocyte growth factoroverexpressing human umbilical cord blood-derived mesenchymal stem cells on liver fibrosis in rats. Cell Biol Int 38: 106-116, 2014. https://doi.org/10.1002/cbin.10186

SHAMS S, MOHSIN S, NASIR GA, KHAN M, KHAN SN: Mesenchymal stem cells pretreated with HGF and FGF4 can reduce liver fibrosis in mice. Stem Cells Int 2015: 747245, 2015. https://doi.org/10.1155/2015/747245

SHARMA RR, POLLOCK K, HUBEL A, MCKENNA D: Mesenchymal stem or stromal cells: a review of clinical applications and manufacturing practices. Transfusion 54: 1418-1437, 2014. https://doi.org/10.1111/trf.12421

SHEN C, LIE P, MIAO T, YU M, LU Q, FENG T, LI J, ZU T, LIU X, LI H: Conditioned medium from umbilical cord mesenchymal stem cells induces migration and angiogenesis. Mol Med Rep 12: 20-30, 2015. https://doi.org/10.3892/mmr.2015.3409

VALADI H, EKSTROM K, BOSSIOS A, SJOSTRAND M, LEE JJ, LOTVALL JO: Exosome-mediated transfer of mRNAs and microRNAs is a novel mechanism of genetic exchange between cells. Nat Cell Biol 9: 654-659, 2007. https://doi.org/10.1038/ncb1596

VOLAREVIC V, AL-QAHTANI A, ARSENIJEVIC N, PAJOVIC S, LUKIC ML: Interleukin-1 receptor antagonist (IL-1Ra) and IL-1Ra producing mesenchymal stem cells as modulators of diabetogenesis. Autoimmunity 43: 255-263, 2010. https://doi.org/10.3109/08916930903305641 
VOLAREVIC V, ARSENIJEVIC N, LUKIC ML, STOJKOVIC M: Concise review: Mesenchymal stem cell treatment of the complications of diabetes mellitus. Stem Cells 29: 5-10, 2011. https://doi.org/10.1002/stem.556

VOLAREVIC V, NURKOVIC J, ARSENIJEVIC N, STOJKOVIC M: Concise review: Therapeutic potential of mesenchymal stem cells for the treatment of acute liver failure and cirrhosis. Stem Cells 32: 2818-2823, 2014. https://doi.org/10.1002/stem.1818

WAN YM, LI ZQ, LIU C, HE YF, WANG MJ, WU XN, ZHANG Y, LI YH: Mesenchymal stem cells reduce alcoholic hepatitis in mice via suppression of hepatic neutrophil and macrophage infiltration, and of oxidative stress. PLoS One 15: e0228889, 2020. https://doi.org/10.1371/journal.pone.0228889

WANG W, GUO H, LI H, YAN Y, WU C, WANG X, HE X, ZHAO N: Interleukin-35 gene-modified mesenchymal stem cells protect concanavalin A-induced fulminant hepatitis by decreasing the interferon gamma level. Hum Gene Ther 29: 234-241, 2018. https://doi.org/10.1089/hum.2017.171

XU LJ, WANG SF, WANG DQ, MA LJ, CHEN Z, CHEN QQ, WANG J, YAN L: Adipose-derived stromal cells resemble bone marrow stromal cells in hepatocyte differentiation potential in vitro and in vivo. World J Gastroenterol 23: 6973-6982, 2017. https://doi.org/10.3748/wjg.v23.i38.6973

XU T-B, LI L, LUO X-D, LIN H: BMSCs protect against liver injury via suppressing hepatocyte apoptosis and activating TGF- $\beta 1 /$ Bax singling pathway. Biomed Pharmacother 96: 1395-1402, 2017. https://doi.org/10.1016/j.biopha.2017.11.023

YAN Y, XU W, QIAN H, SI Y, ZHU W, CAO H, ZHOU H, MAO F: Mesenchymal stem cells from human umbilical cords ameliorate mouse hepatic injury in vivo. Liver Int 29: 356-365, 2009. https://doi.org/10.1111/j.1478$\underline{3231.2008 .01855 . \mathrm{x}}$

YANG B, DUAN W, WEI L, ZHAO Y, HAN Z, WANG J, WANG M, DAI C, ZHANG B, CHEN D, CHEN Z: Bone marrow mesenchymal stem cell-derived hepatocyte-like cell exosomes reduce hepatic ischemia/reperfusion injury by enhancing autophagy. Stem Cells Dev 29: 372-379, 2020. https://doi.org/10.1089/scd.2019.0194

YANG FY, CHEN R, ZHANG X, HUANG B, TSANG LL, LI X, JIANG X: Preconditioning enhances the therapeutic effects of mesenchymal stem cells on colitis through PGE2-mediated T-cell modulation. Cell Transplant 27: 1352-1367, 2018. https://doi.org/10.1177/0963689718780304

YE Z, LU W, LIANG L, TANG M, WANG Y, LI Z, ZENG H, WANG A, LIN M, HUANG L, WANG H, HU H: Mesenchymal stem cells overexpressing hepatocyte nuclear factor-4 alpha alleviate liver injury by modulating antiinflammatory functions in mice. Stem Cell Res Ther 10: 149, 2019. https://doi.org/10.1186/s13287-019-1260-7

YU J, CAO H, YANG J, PAN Q, MA J, LI J, LI Y, LI J, WANG Y, LI L: In vivo hepatic differentiation of mesenchymal stem cells from human umbilical cord blood after transplantation into mice with liver injury. Biochem Biophys Res Commun 422: 539-545, 2012. https://doi.org/10.1016/j.bbrc.2012.04.156

YU Y, YAO A H, CHEN N, PU LY, FAN Y, LV L, SUN BC, LI GQ, WANG XH: Mesenchymal stem cells overexpressing hepatocyte growth factor improve small-for-size liver grafts regeneration. Mol Ther 15: 1382-1389, 2007. https://doi.org/10.1038/sj.mt.6300202

YU YB, SONG Y, CHEN Y, ZHANG F, QI FZ: Differentiation of umbilical cord mesenchymal stem cells into hepatocytes in comparison with bone marrow mesenchymal stem cells. Mol Med Rep 18: 2009-2016, 2018. https://doi.org/10.3892/mmr.2018.9181

ZHANG L, SONG Y, CHEN L, LI D, FENG H, LU Z, FAN T, CHEN Z, LIVINGSTON MJ, GENG Q: MiR-20acontaining exosomes from umbilical cord mesenchymal stem cells alleviates liver ischemia/reperfusion injury. J Cell Physiol 235: 3698-3710, 2020. https://doi.org/10.1002/jep.29264

ZHANG S, JIANG L, HU H, WANG H, WANG X, JIANG J, MA Y, YANG J, HOU Y, XIE D, ZHANG Q: Pretreatment of exosomes derived from hUCMSCs with TNF-alpha ameliorates acute liver failure by inhibiting the activation of NLRP3 in macrophage. Life Sci 246: 117401, 2020. https://doi.org/10.1016/j.lfs.2020.117401

ZHANG Y, CAI W, HUANG Q, GU Y, SHI Y, HUANG J, ZHAO F, LIU Q, WEI X, JIN M, WU C, XIE Q, ZHANG Y, WAN B, ZHANG Y: Mesenchymal stem cells alleviate bacteria-induced liver injury in mice by inducing regulatory dendritic cells. Hepatology 59: 671-682, 2014. https://doi.org/10.1002/hep.26670 
ZHENG J, CHEN L, LU T, ZHANG Y, SUI X, LI Y, HUANG X, HE L, CAI J, ZHOU C, LIANG J, CHEN G, YAO J, YANG Y: MSCs ameliorate hepatocellular apoptosis mediated by PINK1-dependent mitophagy in liver ischemia/reperfusion injury through AMPKalpha activation. Cell Death Dis 11: 256, 2020. https://doi.org/10.1038/s41419-020-2424-1

ZHENG J, LI H, HE L, HUANG Y, CAI J, CHEN L, ZHOU C, FU H, LU T, ZHANG Y, YAO J, YANG Y: Preconditioning of umbilical cord-derived mesenchymal stem cells by rapamycin increases cell migration and ameliorates liver ischaemia/reperfusion injury in mice via the CXCR4/CXCL12 axis. Cell Prolif 52: e12546, 2019. https://doi.org/10.1111/cpr.12546

ZHOU X, CUI L, ZHOU X, YANG Q, WANG L, GUO G, HOU Y, CAI W, HAN Z, SHI Y, HAN Y: Induction of hepatocyte-like cells from human umbilical cord-derived mesenchymal stem cells by defined microRNAs. J Cell Mol Med 21: 881-893, 2017. https://doi.org/10.1111/jcmm.13027 